\title{
Privilege, Access, Shunning: Familial Homophobia and Its Representations in the Works of Sarah Schulman
}

\begin{abstract}
In her book Ties That Bind: Familial Homophobia and Its Consequences (2009) Sarah Schulman explores the way in which heterosexual privilege interacts with the institution of family, and criticizes its destructive impact on familial relationships. According to her theory, the basis of homophobia is a pleasure principle inscribed in the image of family which encourages every privileged family member to enact their dominance on the excluded. Although Schulman has expressed this idea in clear theoretical terms much later, I argue that it has been a visible element of her writing since the 1980s. This paper demonstrates how the author expressed this idea in the past using diverse sociocultural contexts, and how numerous plots from her oeuvre serve as examples to mechanisms of familial homophobia discussed in Ties That Bind.
\end{abstract}

Keywords: queer, AIDS, family, homophobia, Schulman

\section{Introduction}

Family in Western culture is predominantly defined through the criteria of consanguinity or marital relationship. Both criteria are rooted in the central metaphor of reproduction. Since this immediately excludes any non-reproductive couple from full participation in kinship, such an assumption is inherently heterosexist. For gay people, it is coming out to one's relatives, and the following implied failure to fulfill one's expected reproductive role, that used to mark the departure from the heteronormative role within the infinitely multiplying nuclear family. Unsurprisingly, this institution has been subject to analysis and criticism of queer theorists and activists, while gay people often experimented with alternative forms of kinship that could redefine the criteria of belonging. Sarah Schulman, a proliferate lesbian writer and activist, discussed the family and its role in the intergenerational transmission of homophobia in her book Ties That Bind: Familial Homophobia and Its Consequences. This article aims to explore how the development of Schulman's ideas about blood family and chosen family has been visible in her fiction and argues that it is the latter that she identifies as a potential space for affinity and unconditional love.

The definition of family which is constructed around a heterosexual reproductive couple has a long-standing tradition within the Western culture. In an early anthropological study of the ways in which kinship is understood in the American context David Schneider states: "The blood relationship, as it is defined in American kinship, is formulated in concrete, biogenetic terms. Conception follows a single act of sexual intercourse between a man, as genitor, and a woman, as genetrix." (23) It is the figure of intercourse within the heterosexual dyad, where one half complements the other, which results in the birth of a child that underscores the dominant understandings of kinship. One belongs to a family either through shared genetic material, a testament to the biological apparatus of reproduction, or through marriage, the culturally 
prescript reproductive institution. This constitutes the heterosexual script of how life is supposed to develop.

This reference to a 1968 study of the American family is useful to understand the dominant notions of kinship which predated and likely influenced Schulman's writing project. Since this article attempts to deal with an oeuvre that spans over 35 years, it is necessary to establish a timeline of ideas related to the subject of gay kinship. In 1969, after the Stonewall Inn riots, the gay liberation movement began to argue for embracing gay identity. According to Kath Weston and her study of gay kinship Families We Choose, it was "a period when coming out to relatives witnessed a kind of institutionalization" (41), i.e. the idea of coming out to one's blood family became thinkable. Partly in response to tensions within their blood families, partly because their own relationships were not legally recognized, an idea of chosen family as an alternative way of understanding kinship emerged and gained popularity among gay people in the 1980s. Since the 1990s gays activists have been increasingly expressing the demand for marriage equality, which has influenced greatly the way queer kinship is understood, bringing it closer to a nuclear family. In 2015, the ruling in the civil rights case Obergefell v. Hodges brought about legal recognition of same-sex marriage throughout the United States.

This shift may influence greatly the way in which gay people fit into the American construct of kinship. However, most of Schulman's novels were published in the 1980s and 1990s, and same-sex marriage remains a distant concept in them. Only in Schulman's latest novels, such as Maggie Terry, does same-sex marriage as understood today constitute an element of social life, and even there it does not play a very significant part in the plots. Thus, this article deals mostly with a historical situation in which gay people did not fit into the normative concept of kinship because their relationships were neither recognized legally, nor understood to form nuclear families.

In Ties That Bind, Schulman argues that the experience of being mistreated by their family is one that almost all gay people share. "We have each, at some time in our lives, been treated shoddily by our families simply, but specifically, because of our homosexuality" (1). While the degree of displayed homophobia may vary, from microaggressions to disowning and shunning, very few gay people do not suffer any kind of mistreatment from their family. This wrongdoing does not have to take form of the overt acts of homophobia. Since family is expected to provide a network of emotional and economic support, the mistreatment often manifests as acts of withholding. As Rayna Rapp claims in an article on family and class, "it is within families that people experience the absence or presence, the sharing or witholding (sic), of basic poolable resources" (281). Thus, being kept away from these resources makes one especially vulnerable. Schulman states that unequal access to family wealth often keeps gay people at a financially disadvantageous position that helps in their subjugation. It is due to the threat, spoken or unspoken, to withhold the resources that gay people are kept within the family structure, yet treated as its second-class members. This mechanism can be also translated into emotional support that families grant.

Schulman explores a complex relationship between homophobia and various systems of power. In her account, the withholding of support is often enacted by the relatives indirectly: 
They vote for politicians who hurt gay people; they contribute to religious organizations that humiliate gay people; they patronize cultural products that depict gay people as pathological. They speak and act in ways that reinforce the idea of gay people as 'special interest.' In many ways, the message is clear that the gay person is not fully human. (Ties That Bind 19-20)

The choice of a religion, a political party or a brand that partakes in the oppression of gay people constitutes a betrayal of kinship ties. Yet, it is not construed as such, since empathy and loyalty towards gay kin are considered optional, whereas such bonds with straight kin are not typically put in question by religious or political institutions.

\section{Early Manifestations of the Ideas}

These ideas have been present in Schulman's writing from the very beginning. Her debut novel, The Sophie Horowitz Story, published in 1984, tells the story of a lesbian journalist who investigates the case of a bank robbery committed by feminist Marxist radicals. Sophie's relationship with her parents is mentioned for the first time as the protagonist reminisces about her childhood fascination with such radicals. Her mother was thankful that Sophie, already displaying signs of disobedience as a child, had been born too late to become a communist. Later, after Sophie comes out, the mother castigates her, compares to a drug addict, and threatens to sell the house and move somewhere where no one would know about her. She also imagines reasons for her homosexuality to be some kind of dysfunction: "Your problem is that you never accepted that you're a woman. Your father says it's all my fault because I took you to see Martin Luther King and that you hit your head a lot when you were little, the gay thing I mean" (64). These notions are grounded in an understanding of homosexuality as the orientation that lacks something (e.g. reproductive potential or a partner that differs from one in the crucial categories of sex and gender), whereas heterosexuality is the only full, intended and natural order of sex.

While the next novel, Girls, Visions, and Everything paid less attention to familial homophobia, it does include a scene where Lila, its main character, considers an idea for a story:

\footnotetext{
You know Lacy, for years I've been trying to figure out parents, since I've never been one, just had them. But now, I get it. They live their lives and then they want to live yours too. Gives me an idea for a story. Something about parents who only want one thing in the world and that's for their child to fail so that they can prove that they were right all along. (55)
}

Lila perceives parents to be, universally, people who want to control the lives of their children and would rather see them fail and be right than witness their success and be wrong. This is in line with the novel's larger themes of gay community and its common experiences; Schulman's contention in Ties That Bind that familial abuse is almost a universal experience for gay people is already visible here in Lila's offhanded criticism of family that is to be expected from a lesbian. 
It is also Girls, Visions and Everything where a rare example of Schulman's positive portrayal of familial relations can be found. In the novel's final chapters Lila encounters among various contingents in Pride parade relatives that come out to support their gay kin: "She cheered Grandmas for Gays and felt, yet again, overcome to the point of tears at the sight of Parents of Gays, with their handpainted signs, 'We Love Our Gay Children" (127). The rare cases of relatives who are invested in the reality of lives of their gay kin enough to take part in Pride are presented as a positive example of familial love. Yet the scene serves a double purpose, as Lila's tears are a sign of her own experience of familial homophobia, not suggested anywhere but for the previously discussed idea for a story. It is precisely due to the ubiquity of familial homophobia that Lila's response is decipherable as an index of abuse since abuse is expected to have happened.

Schulman's fourth novel, People in Trouble, is her first one to cover the AIDS epidemic. Moments of the high visibility of familial homophobia are thus related to death and mourning. Towards the end of the novel one of the gay characters, Scott, dies of AIDS. His life partner is entirely omitted in The New York Times obituary:

The New York Times obituary said that Scott was 'survived' by two daughters, a wife, mother, father, and sister in Kansas City.

Then Kate found a privately placed notice at the bottom of the obituary page.

Scott Yarrow died in the arms of his lover, James Carroll, with whom he shared a vision of freedom for lesbians and gay men. (218)

The sharp contrast between the two areas of mourning brings to light inequality and erasure of queer grief. It is the family understood through the criteria of consanguinity and marriage that is entitled to grieve publicly, and that gets their place in The New York Times official obituary. A gay life partner gets relegated to the private sphere (if they get acknowledged at all), hidden from view. In the time of death, the heterosexual supremacy is enacted through the imposition of the official heterosexual script despite the fact that the deceased resisted this ideology. As gay kin cannot protest anymore, they become reabsorbed into the family on the supremacist terms, at least within the official media narrative. Erasure of Scott's agency and his personality for the sake of propriety is another instance of dehumanization performed by the family.

One more interesting case of the supremacist ideology destroying kinship ties may be found in Schulman's historical novels: Shimmer and The Cosmopolitans. While they both discuss similar mechanics of exclusion as the rest of Schulman's oeuvre, in none of them does homophobia ignite them; Bette, the protagonist of The Cosmopolitans, is not even gay. What causes the exclusion in both cases is the protagonists' failure to adhere to the heterosexual script in relation to marriage. The Cosmopolitans follows Bette's lonesome spinsterhood in the 1950s, which is a result of her exclusion from her family decades earlier. Bette's transgression was a passionate love for a man in her hometown, which resulted in them having sex. On the next day, the man in question was announced to be a fiancé of her cousin. Bette protested and tried to make the man admit publicly the love he had promised her in private, but as he refused to do so and denied they had sex, Bette's family assumed her to be 
jealous and destructive, and shunned her. The transgression of Sylvia, the protagonist of Shimmer, is a more general pursuit of a career in the 1940s, and lack of interest in finding a husband and having children. Bette is given a one-way ticket to a bigger city, whereas Sylvia is the object of her parents' constant criticism and disapproval. Both of the characters are in a sense queer, even if not gay, as they are unwilling to follow the heterosexual script of a nuclear family. The mechanics of punishment are similar regardless of their sexuality.

\section{Acquisition of Power Through Familial Homophobia}

Such examples may be found in any given novel by Schulman, and from now on they may be considered in more detail in relation to particular mechanisms of familial homophobia analyzed in Ties That Bind. Among them there is a lack of congruence between many relatives' politics and their homophobic behavior:

One of the most pervasive uses of homophobia within a family is by family members who actually have no inherent prejudices toward gay people but manipulate their family's prejudices to achieve greater currency internally.... Although theoretically it sounds ridiculous, in applied real life terms it's much easier to love gay people and not stand up for them than to risk your own privileges to have a consistent trajectory of behavior. (36-37)

Thus, it is not only the relatives that are prejudiced against gay people that act homophobic. Instead, familial homophobia may be enacted by any relative, given it allows them to acquire a better position in the family structure.

This is a dominant theme in Schulman's eighth novel, The Child, which tells the story of Stew, a gay teenager who has an affair with a middle-aged gay couple, and who is arrested for trying to pick up a policeman at a public restroom. Stew's parents consider their son a pervert and send him to a therapist to "heal" him of homosexuality. His sister, Carole, who has a husband and a child, uses this situation to secure her superior status within the family. In one scene, Carole's son talks to his gay uncle and Stew says things that, he realizes, his family would not want him to share with the little boy. The nephew obediently does not disclose the subject of their conversation, but he does tell his mother and grandmother that uncle Stew wants him to keep a secret something that happened between them. At that point it is up to Carole how to interpret and resolve the situation:

Carole looked at him with confusion. She was making a decision. She could have just understood that nothing bad had happened and been okay with that. Been his friend. But then she would have lost all that special ground she'd gotten with her mom. All the conspiracy. She'd have lost all the points she'd gotten for getting pregnant, just like her mother, and then getting Sam to marry her, just like Brigid had with Dad. She could have that special status if Stew was twisted, a pervert. If he was okay, she'd lose everything.

'Mommy,' she screamed. 'Mom.' (157) 
Carole chooses to imply that Stew has done something wrong. She uses the homophobic metonymical switch from homosexuality to pedophilia to pathologize her brother. As a result, she secures her position as the favorite child. Stew, on the other hand, is thrown out of the house, but Carole cares little about that development. Her motivation has nothing to do with her homophobic prejudice, as her actions are driven by an attempt to win her mother's approval.

Another instance of similar dynamics is represented in the sibling relationship in Shimmer, Schulman's seventh novel. Its protagonist, Sylvia, works as a secretary for a newspaper, and her ambition is to become a reporter and have a successful career in journalism. As previously mentioned, the story takes place in the 1940s, after the war, so her plan moves beyond the expected narrative of a woman's life. In the course of the novel, Sylvia is repeatedly castigated by her parents but enjoys a good rapport with her brother, Lou. He is the favorite of their parents, but her savvy and ability make her successful at work and keep them equal; Lou sometimes protects his sister from their parents' disapproval, or at least is empathic to her, and Sylvia, in turn, helps him deal with problems of entering into adulthood.

Interestingly, the alliance between the two seems to be an evolution of the sibling relationship in The Sophie Horowitz Story. Sophie's brother is also named Lou, and they also have a good, mutually supportive relationship. However, while in Schulman's debut novel the relationship never goes awry, in Shimmer the shift in power dynamics diffuses their solidarity. At one point, Sylvia secures a job for Lou at her workplace. Quite quickly, and not based on his achievements, Lou is offered the position that Sylvia has been seeking for years. At first, Lou refuses out of loyalty and recommends Sylvia for the job. Soon, however, he is persuaded by his boss to give in to his wish to become Sylvia's superior:

'Lou, have you ever been the best at anything?'

'No, sir, I have not.'

'Well, now you are. Now you can call up your father and tell him that for once in your life you are the best qualified. Think of how proud he will be of you. Sylvia's been the best many times I'm sure...'

'But...' he stammered in that dislocating transitional phase when a person suddenly realizes that they have no support. That whatever position they're taking is not the favored position and cannot ultimately win. When they start to see this inevitability, often they simultaneously start to calculate exactly how much loss will be involved in sticking with that increasingly improbable position, and how they are going to shake the responsibility of it. (149)

For Lou, remaining loyal to his sister would mean rejection of the opportunities granted to him by his male privilege. The way in which Schulman depicts mechanics of sexism enacted by a man who is not overtly sexist mirrors her ideas on the use of homophobia by the non-homophobic relatives.

\section{False Accusations and Avoiding Discomfort}

Schulman often uses the theme of sibling rivalry to represent the mechanism of betrayal. As Kath Weston's study of chosen families found, "siblings in general were 
presumed to be more accepting than either fathers or mothers" (54). This may be related to the fact that the siblings are one generation younger than the parents, which fits the narrative of progressive spread of tolerance and eventual acceptance of gay people. Schulman argues, however, that with each generation the homophobia does not disappear, but it is only the tactics that change:

Whereas your grandparents may have thought you would burn in hell, your parents may have called you once a month but refused to allow your lover in their home. Your sister may let you and your lover come over for Thanksgiving but not let you be alone with her children.... A forty-year-old woman living in New York City today probably cannot tell her friends, or herself, that she hates her brother because he's gay.... Instead, she'll just find another reason that is more generationally suitable. As one straight colleague on a job told me, 'It's not your homosexuality that I hate. It's your clothes.' (Ties That Bind 59-60)

Instances of finding a more suitable reason, usually through false accusations, are a result of the discourse of tolerance. Since gay people have articulated the ways in which they are being excluded in a way persuasive enough to break to the mainstream media, the more overt displays of homophobia may result in some sort of accountability. This causes readjustment of the homophobic position so that the accountability can be avoided, yet the heterosexual supremacy may remain intact. As younger people, in general, are often assumed to be more progressive, and as the competition for parental approval has always been a part of relationships between brothers and sisters, sibling rivalry is a fertile ground for exploration of this idea.

The particular mechanics of false accusations among the siblings are explored in The Child. One of its many plots follows the story of Eva, a lesbian lawyer shunned from her family. Eva finds out that her sister had a child, but the pregnancy was kept secret from her, and the family does not want her to know the child. This is another in the long line of insults and dehumanizing gestures she is subjected to. Eva is willing to forgive them all, but the family remains abusive:

First they humiliated her for being gay, so she became alienated. Sequence, consequence.

But because the family viewed the initial humiliation as fine, Eva being upset about it was only further proof of how bad and wrong she was.... That was the familial 'modus o' from 1975 to 1992. At that point, because of AIDS there was a social shift, and the kind of vulgar homophobia the Krasner family dutifully practised went out of fashion.... Now they no longer cited the homosexuality as the justification for their cruelty. They now pointed to the consequences of their cruelty as its own justification. Eva being alienated was now reason enough to keep her that way. What had caused it became unmentionable. (110-111)

Eva's family's choice to exclude her through overt homophobia requires only slight readjustment in order to not appear homophobic. Rather than shunning her for being gay, she is being shunned because she is making the family uncomfortable. What actually causes the discomfort is being accountable for the hurt they previously caused. Since they stand nothing to gain by reconciliation, and it would make them 
uncomfortable, they remain loyal to their initial shunning and react to the shift in social acceptability of exclusion by changing the explicit reason.

The tactics discussed by Schulman in the above example are quite often intuitive and invisible to the heterosexual majority. As she claims in Ties That Bind, "throughout the history of cruelty to gay people, exclusion has consistently been theorized as a natural unquestioned option" (35). Its being "natural" and "unquestioned" is extremely important to the comfort of those who benefit from the heterosexual supremacy. In "Queer Feelings," Sara Ahmed discusses the relationship between the comfort of dominance and invisibility of its boundaries:

\begin{abstract}
Normativity is comfortable for those who can inhabit it.... We don't tend to notice what is comfortable, even when we think we do... To be comfortable is to be so at ease with one's environment that it is hard to distinguish where one's body ends and the world begins. One fits, and by fitting, the surfaces of bodies disappear from view. (425)
\end{abstract}

It is precisely in the invisibility of boundaries where the quality of comfort lies. As one fits a dominant cultural script, its demands and restrictions seem so natural and intuitive as to be no more exclusive than the laws of gravity are. Hence, dissent to exclusion may be easily dismissed from the position of dominance, while enactments of homophobia may remain ubiquitous despite the discourse of tolerance. Invisibility makes the heterosexual supremacy both advantageous for its beneficiaries, thus securing their loyalty to the system of power, and comfortable, so that maintenance of these power relations is easy and intuitive, while resistance to them is difficult and distressing.

Schulman's novels often include representation of such resistance and the punishment in which it results. The characters who benefit from unequal power relations tend to protest claims of those who try to make visible the boundaries of these power relations. In Shimmer, after Lou accepts the promotion, Sylvia wants him to return to his initial, loyal position, which was a refusal to take the job and recommendation of his sister as a better fit. Both are fully aware that she has actually earned the promotion, and Lou has not. However, having accepted the offer, Lou begins to explain calmly to his sister his right to use his privilege: "Maybe some things aren't as fair as you would like, but the world isn't fair.... You go blaming everything on being a girl, but you're never going to be a man no matter how hard you try. And that's what Mr. O'Dwyer wants" (153). This explanation works for Lou: the male supremacy is natural, and therefore there is no point in challenging it. Since there is no point in challenging it, he might as well benefit from it and take the job. Faced with betrayal from her beloved brother, Sylvia screams and loses control, insulting him. Lou's defense, in turn, becomes harsher: "According to your screwed-up logic, anything I get in this world is because I'm not a girl. And anything you don't get is because you are. Jesus" (153). At this point, Lou begins to blur the boundaries between his privilege and his merit, distorting Sylvia's argument. His anger at his sister's relentless attempts to keep him accountable, rather than accept the result secured by the male supremacy, catalyzes the growth of his burgeoning sense of superiority. After Sylvia implores him to turn down the job a few more times, he ends up repeatedly dehumanizing her: 
'Pop was right,' he said, filled with the absolution from responsibility that condescension always implies. 'You're an animal. You tried to get me in trouble with Pop, and now you want to take my job away.... I've made it now... I've got all the connections. And I'm going straight to the top where bitches like you can't come near me.' (154)

Lou's behavior is in accordance with the patriarchal power relationships. Sylvia's requests to act differently repeatedly show him the agency he has in the situation, even though the system of power attempts to mask itself and make him its natural beneficiary. Her actions make Lou uncomfortable, enrage him and make him enact his dominance, even though up until this moment he has looked up to his sister.

As Lou betrays his sister, he begins to use every advantage he has over her in social and family structure to keep her in the inferior position. This is first marked by his shift of loyalties, the move away from Sylvia and towards their sexist father. It manifests quickly by false accusations of "trying to get his job away," which becomes his official line of defense in this conflict. Later, Sylvia seeks resolution through a mediation by their parents. She has been, however, outrun by Lou, who has already convinced the rest of the family to his version of the story:

'He told us what you did to him... you told Lou he had no talent? You said such a horrible thing to your brother? I shouldn't even let you in the house.'

'That is not what happened,' I yelled. Yelling confirmed, of course, my monstrosity. That I could be annihilated by their hate proved that it was true.... 'Lou violated our relationship just to get ahead in the job. And it's not going to get him anywhere anyway because he's not even qualified and can't pull it off. Then he went running to you to cover it up.'

'He needs money because he's gonna have a family.'

'Anything your brother does,' Mama said flatly, 'is all right with us.' (184)

While earlier Lou used to resist his family to protect Sylvia, there never was anything at stake for him personally. Actually, he was rewarded for such behavior, as his superior position in the family was secure, and Sylvia responded to protection with trust and help. Once she becomes an obstacle, however, Lou immediately uses the power he has as a man and his position in the family to stop her. The parents, who could become mediators, are partial to Lou as the one in whom they see the potential of following the heterosexual script of marriage and children. This, by itself, becomes an argument that justifies his betrayal. Sylvia's resistance is constructed as an act of abuse, while the actual violation is kept invisible by the family.

In Rat Bohemia, which is Schulman's sixth novel, David, a Person With AIDS, repeatedly tries to make his family acknowledge the epidemic by telling them incessantly about his dying friends. They usually do not respond in any way, since their homophobia makes acknowledgment of relationships David has with other gay men uncomfortable for them. However, in one scene his sister grieves the death of her elderly graduate school professor. The mother reacts to this loss empathically, saying: "You've had more people die in your life than anyone I know" (87). This strikes David as blatantly untrue, but he does not even manage to respond before he is faced with 
his mother's accusation: "You mean the AIDS thing.... You're always looking for ammunition against us" (87). David's sister's loss is a part of the heterosexual world, as professor-student relationships are familiar to it. David's countless losses of other People With AIDS, however, are outside of the heterosexual script, because they were the relationships he had built in the gay community. His intervention would render this discrepancy visible, which is why the mother anticipates and undercuts his possible response and immediately blames him for making the rest of the family uncomfortable. This way, David becomes responsible for the tension, and the homophobia within the family is protected.

\section{Internalized Homophobia and Alignment with Power}

Deflecting through accusation in response to demand for accountability is not practiced by straight people exclusively. As Schulman writes:

The perpetuation of homophobic practice is repeatedly blamed on gay people themselves. We are depicted as being inherently deserving of punishment, even though, in actuality, we have not done anything wrong... Sadly, this paradigm confuses gay people ourselves. Conversely, when we insist on inclusion, full recognition, and access to process, we can get internally pathologized as 'militants,' 'activists,' and 'stalkers,' even by each other. (Ties That Bind 33)

Just like Lou aligned with power when such action was beneficial for him, gay people often act in a way that reinforces the heterosexual supremacy when their own vested interests in its power relations are endangered. These interests may be fueled by their resistance to challenging homophobia in their own family or their sense of superiority over politically active gay people enacted through disowning of gay identity politics. In such cases, the accusation is also used as a defensive mechanism.

This is, at least partly, the case of Muriel Kay Starr, a lesbian novelist in Rat Bohemia. Muriel writes popular fiction that does not touch upon the theme of homosexuality in any way, and her own sexuality is carefully erased from her writing or even blurbs of her books. Muriel had a feud with David, the previously mentioned gay man with AIDS, who was also a writer, albeit an unknown one. After his death, she tells the story of their friendship, giving a detailed and convincing account of his jealousy due to her success and his failure, ascribing the negative emotion to David's sexism. However, when the character who listens to this story recalls the actual contents of David's complaints, which was that Muriel's work was closeted, the author becomes defensive:

'I am so out. It says there that I've written for Genre magazine.'

'But what straight person is going to have ever heard of Genre magazine?'

'Don't tell me what to do ... David was jealous. You read my book before you complain. It's not about that. My books are not about homosexuality. They're about family. I wasn't even that famous yet and he was terribly jealous.' (170)

Muriel's defense is proven untruthful by the end of the book, as its appendix comprises four chapters of her novel, which tells the stories of gay characters in Rat Bohemia, 
only turned into straight people. Thus, her fiction is based on the lives of gay people but carefully adjusted to cater to the heteronormative public. When faced with a challenge, Muriel deflects the criticism by scapegoating David as sexist.

Such a gesture performed by one gay person on another is not uncommon in Schulman's works. In fact, her argument in Ties That Bind is that since "the family is the place where most gay people are first instructed in homophobia" (32), gay people learn there that they can dehumanize one another. This early experience teaches them that they are inferior, but also that all gay people may be treated as inferior and cannot demand accountability. This translates into the way in which people treat each other in same-sex couples:

All homosexual lovers have watched the person who has given them pleasure, friendship, caring, love and kindness be repeatedly humiliated by their family, by cultural representation, and/or by the state. So, when the time came when it was convenient to pretend away any responsibility to that person, the simplest thing to do was to imitate the cruelty they had already always endured. (82-83)

The systematic oppression is invisible and often accepted to some extent by gay people themselves. While the heterosexual supremacy often punishes and excludes them, sometimes it may also benefit them, at least in short term. In such cases, they too tend to act as if the same-sex relationships they have been building, and their partners, did not matter. Since there used to be no structures, legal or familial, to obstruct the dehumanization of a lover, partners in couples were extremely vulnerable to each other.

Such is the story of Anna, the protagonist of Schulman's fifth novel, Empathy. In one of her psychoanalytic sessions, Anna discloses to her therapist: "I never had a lover who would let me meet her parents." The reasons for such situation varied from partner to partner, including orphanhood and being disowned, but internalized homophobia of her lovers appears among them: "But there were also times, Doc, when the women were... ashamed of me. It was because they were ashamed of me. Because they thought I was less. Because they didn't want to make their families uncomfortable, so they made me uncomfortable instead" (74). Then she goes on to describe the time when she set out on the journey through the United States with her lover, Sarah. During the journey, Sarah cheated on her sleeping with men. By the time the two got closer to Sarah's family home, she "had gone straight conveniently" (75) and they were no longer lovers. Sarah was too scared to come out to her homophobic family, and she acted it out on her girlfriend.

Another vivid example of such mistreatment between gay lovers is presented in Schulman's eleventh novel, Maggie Terry. Its eponymous protagonist is a lesbian who has been institutionalized for her alcohol and drug addiction. She used to be in a long-time relationship with a woman named Frances and they decided to have a child. Frances is the biological mother of their daughter, Alina, but the couple raised her together. After Maggie has been institutionalized, Frances won full custody of their child. Since Maggie sought necessary help after Frances's intervention, she believes that if she fights her addiction, she could still be present in Alina's life. However, by the time she is out, Frances has moved in with another woman and has no intention of letting Maggie anywhere near their child. The women were not married, so there are 
no legal grounds on which the protagonist could fight for visitation rights. No one in Frances's family is willing to intervene on Maggie's behalf, either, because families do not consider the partners of gay kin to be relatives. In Maggie Terry, Schulman represents how partners can use both social and legal norms of mistreating gay people against each other.

This particular dynamics is, in Schulman's opinion, the actual reason for advocating gay marriage. Since gay activism began to focus on marriage equality, it tended to depict the oppressive results of state ignoring same-sex relationships, such as the inability to visit hospitals or inherit property. However, Schulman argues that the demand for gay marriage stems from a fear of being mistreated by other gay people. "Gay marriage does not so much protect the couple from the state, as it protects the couple from each other. It is a third party acknowledgment and recognition that people who have shared love have basic responsibilities toward each other" (118). That idea is represented in the author's ninth novel, The Mere Future, which is set in the unspecified future where same-sex marriage is allowed. Its narrator has been in a relationship for a long time, and she proposes to her girlfriend, Nadine, who responds by saying: "I'm old school... I'd rather live in sin." (162) However, her refusal is not a mere whim; rather, it is a way of keeping her options open. In the course of the novel, Nadine moves away from initial loyal and close relationship and establishes a distance that seems to lead towards the couple's breakup. She becomes increasingly disinterested with the narrator and briefly falls in love with another woman. Nadine's refusal to marry the narrator is a sign of her preference to remain unaccountable for the way she behaves towards her partner.

\section{Chosen Families and Uncomfortable Love}

At times, however, Schulman employs more optimistic depictions of her queer characters' relationships. Even though gay people are often being mistreated by each other and by their families, there is a space for negotiation and resistance to the homophobic paradigm. This is linked to the idea of gay families, or chosen families, which emerged in the gay community in the 1980s. Kath Weston defines them in Families We Choose this way: "Gay or chosen families might incorporate friends, lovers, or children, in any combination. Organized through ideologies of love, choice, and creation, gay families have been defined through a contrast with what many gay men and lesbians in the Bay Area called 'straight,' 'biological,' or 'blood' family" (27). While biological families are organized by the principle of consanguinity, gay families, understood as networks of close relationships, are organized by a principle of choice. Weston links this development to the emergence of the practice of coming out to the families after the Stonewall Inn riots. Relatives' response to such revelations was often unpredictable and gay people were anxious that their families would disown them. Interestingly, the very idea that one can lose one's family made the way kinship is constructed more visible. An act of disowning became a real possibility in the lives of many gay people. Since such action can sever the ties of kinship, it follows that not only blood ties make a family. Conversely, one can also consider people with whom there is no blood tie to be their family. This caused gay people to notice the role the idea of volition plays in the notion of kinship. 
This kind of voluntary kinship is the space in which Schulman has repeatedly represented possible resistance to familial homophobia and its consequences. The Child shows the positions of loyalty and scapegoating in stark contrast as Stew's story comes to an end. The legal team defending David, Stew's adult lover, comprises two gay lawyers: Hockey and Eva. The former is a Person With AIDS, who desperately tries to cling to his status and needs to win a case for his own comfort. The latter takes the case because she feels a bond of kinship with David, whom she considers a victim of the unjust system, as his punishment for an affair with a minor might be severely aggravated because he is gay. In the course of the plot Stew, driven mad by his family, kills his nephew. Hockey's plan is to scapegoat the boy with a line of defense that would exonerate David, but worsen Stew's position in the murder trial. Eva disagrees with this tactic on ethical grounds: "Hockey wanted to argue in court that Stew was responsible for his actions, in order to get David off the hook. But that was not the truth. Stew was driven to murder. But not by Dave. He was driven to it by people who would never be put on trial. Eva couldn't pretend it was any other way" (255). Both lawyers know well that it is the homophobic family who is really responsible for the tragedy. However, Hockey is completely aware that enactment of familial homophobia is considered natural in the system of heterosexual supremacy, and thus the family cannot be held responsible. His focus is winning the case, and so he is willing to help with scapegoating for the benefit of his own agenda. Eva, on the other hand, stands her moral ground and develops a sense of kinship with the boy: "His family didn't want him. He's gay. Other gay people are his family. Stew is our child" (229). Since he does not have the protection of his family because he is gay, Eva considers it her and other queer people's moral responsibility to protect him and include him in an imagined gay family. This gesture of inclusion is resistant to the ideology of familial homophobia. Eva chooses to keep perceiving Stew as human, and she considers his fate just as important as anyone else's, even though she stands to gain nothing from that, and might lose a lot.

Perhaps the most explicit example of a chosen family as a site for unconditional love is the conclusion of Schulman's tenth novel, The Cosmopolitans. As previously described, it is set in the 1950s and its plot covers the spinsterhood of Bette, who has been scapegoated and disowned by her family. She shares a profound friendship with her door-to-door neighbor, Earl, who is a single black gay man. In the course of the novel Earl manages to gain some currency by pretending he is heterosexual and shuns Bette when she wants to discuss the subject. After the situation enabling Earl's lie ends, he comes to his friend and apologizes. Healing is enabled by Earl's willingness to admit his fault and complicity in the heterosexual supremacy, and Bette's openness to listen. This idea is articulated in a manifesto-like passage in the middle of the conflict that represents Bette's thoughts as she grapples with Earl's shunning:

There are many different kinds of love. True, novels and cinema, the work of culture and commerce, have prepared all to believe that only two really matter: the romantic pairing of a man and woman and the love between parent and child. Every message trumpets these as everlasting, of central importance, and beyond evaluation or reproach. But in Bette's experience, neither claim was true....

'Love,' in these examples, was an enactment of value. It was an assertion of place in the social order. It meant everything on the outside and little within. 
Bette looked inside herself and knew for a fact that the love she had for Earl and he for her - the years of loyalty, the time, the confiding, the rooting for, the thinking of, and now her unfaltering faith that he could ultimately do the right thing, the acceptance of conflict, and the refusal to shun him - that all this was more powerful than the twisting and discarding that took place between blood relations. Than the deceptions that transpired between lovers. She knew that this love should be the center of novels and poems and plays, operas and such, but it couldn't be. Because then all the falsity would be exposed in comparison- to love when you are not supposed to is so much deeper than to love as instructed to do. $(239-241)$

While cultural representations of love center on familial ties of parenthood and heterosexual marriage, Bette considers them to be too implicated in relations of status, custom, propriety and social currency to offer unconditional love. In contrast, voluntary kinship ties are not supported by any external incentives, and there is a possibility they may rely predominantly on mutual affection. This is why Bette's family can shun her throughout her life since admitting wrongdoing would cost them currency, make them uncomfortable, and question their superiority; and this is why Earl, on the other hand, can apologize and be forgiven once he realizes he does not need to be superior.

\section{Conclusion}

In Ties That Bind, Sarah Schulman analyzes the mechanisms of familial homophobia. She claims that the experience of being mistreated by a family is common to almost all gay people, which is reflected in the ubiquity of this experience among characters in her novels. Schulman pays particular attention to the exchange that occurs when people who are not prejudiced themselves, sacrifice the relationship with their gay relatives in favor of social currency. She represents this mechanism and shows how questioning of such behavior, as well as any other mechanism of familial homophobia, causes scapegoating and shunning. Because homosexual people learn in their families that they are inferior, and they can be mistreated, it is often the case that her queer characters use supremacist assumptions to their own advantage, at the expense of other gay people. However, chosen families that queer people form are less invested in the systems of power, and thus Schulman represents them as a potential site for unconditional love that may be a space of dissent from the familial homophobia and its consequences. The author suggests that it is such unwavering loyalty that may fuel resistance to the lure of rewards offered by the heterosexual supremacy and transform the unequal power relations.

\section{Works Cited}

Ahmed, Sara. "Queer Feelings." The Routledge Queer Studies Reader, Routledge, 2013, pp. 422-441.

Rapp, Rayna. "Family and Class in Contemporary America: Notes toward an Understanding of Ideology." Science \& Society, vol. 42, no. 3, 1978, pp. 278300 . 
Schneider, David Murray. American Kinship: A Cultural Account. University of Chicago Press, 1980.

Schulman, Sarah. Empathy. Dutton, 1992.

—. Girls, Visions, and Everything. The Seal Press, 1986.

—. Maggie Terry. Feminist Press, 2018.

- People in Trouble. Plume, 1990.

- Rat Bohemia. Dutton, 1995.

-. Shimmer. Quill, 1998.

—. Ties That Bind: Familial Homophobia and Its Consequences. The New Press, 2009.

- The Child. Carroll \& Graff, 2007.

- The Cosmopolitans. Feminist Press, 2016.

-. The Mere Future. Arsenal Pulp Press, 2009.

- The Sophie Horowitz Story. The Naiad Press Inc, 1984.

Weston, Kath. Families We Choose: Lesbians, Gays, Kinship. Columbia University Press, 1997. 
